\title{
GORDON ARTHUR RILEY: THE COMPLETE OCEANOGRAPHER 1911-1985
}

\author{
DONALD C. GORDON* \\ 1 Prince Street, Suite 502 \\ Dartmouth, NS \\ $B 2 Y 4 L 3$
}

\begin{abstract}
Gordon Riley was an outstanding scientist who played a leading international role in the development of oceanography as a field of scientific study in the mid-twentieth century. His multidisciplinary approach, quantitative skills, imagination and intuition advanced our knowledge and understanding of the ocean enormously. Of his many significant scientific contributions to oceanography, he is best known for his pioneering work in developing simple numerical models for improving the understanding of the dynamics of marine ecosystems with a focus on plankton. He helped transform oceanography from a descriptive to a quantitative science. His early career was spent in the United States at the Bingham Oceanographic Laboratory of Yale University and the Woods Hole Oceanographic Institution. In 1965, at the peak of his career, he immigrated to Canada to become the director of the Institute of Oceanography at Dalhousie University. Under his leadership, the Institute evolved into the Department of Oceanography, which became an internationally recognized centre for marine research and teaching. During this period, he also played a prominent role in the development of the broader Canadian oceanographic community. He served as a wonderful example of how scientific research, teaching and a life should be carried out.
\end{abstract}

\section{INTRODUCTION}

This article presents an overview of the life and career of Gordon Riley, a remarkable individual who spent most of his oceanographic career in the United States before immigrating to Canada in 1965 to lead the creation of the Department of Oceanography at Dalhousie University. Recent publications have reviewed his many diverse scientific accomplishments (e.g. Wroblewski 1982, Mills 2012, Anderson and Gentleman 2012, Egerton 2017). This article concentrates on the 
progression of his career as a scientist, teacher and administrator, including some personal information. He had a huge and lasting impact on Dalhousie University and the Canadian oceanographic community.

\section{EDUCATION}

Gordon Riley was born in Webb City, Missouri, a small town located in the Ozarks far from the ocean in almost the geographic centre of the United States. When he was seven, his family moved to nearby Springfield. As a child, Gordon developed a keen interest in the out-of-doors and natural history. He found school boring but became a voracious reader of literature and science. For a while, he considered a possible writing career but later decided to pursue a path in science. After high school, he attended Drury College, a small liberal arts college in Springfield. This was during the Great Depression when money was tight so he lived at home. He took all the science courses available in biology, chemistry, geology, physics and math. During his undergraduate years, he developed an interest in embryology and decided to pursue graduate studies in this field. He applied to several graduate schools and was accepted by Washington University in St. Louis which provided him with a scholarship. Hence, after graduating from Drury College, he moved on to earn a Masters degree in the descriptive embryology of tunicates. His thesis advisor at Washington University encouraged him to continue graduate studies in the new field of experimental embryology and recommended the Department of Zoology at Yale University in New Haven, Connecticut. He applied, was accepted and awarded a teaching assistantship that covered all expenses.

In 1934, Gordon left Missouri for the first time and moved to New Haven, a move that had a huge impact on his subsequent life and career. He thoroughly enjoyed the new experience and saw the ocean for the first time. He started a doctoral program in experimental embryology under the supervision of Ross Harrison but he floundered and found it difficult to find a suitable thesis topic. By chance, during his second semester he took a course in limnology that was taught by Evelyn Hutchinson, a young and dynamic instructor recently arrived at Yale from the UK by way of South Africa. Riley was immediately enthralled with both Hutchinson and the topic and within the first week decided that limnology was the field where he wanted to be. 
There were many challenging questions waiting to be solved and, being a naturally outdoors person, he welcomed the opportunity to conduct field research. Therefore, he changed supervisors and became Hutchinson's first graduate student.

With time, Hutchinson became a world-renowned ecologist who was later honoured with a Celebratory Issue of the journal Limnology and Oceanography (Edmondson 1971). His full life story and extensive accomplishments have been thoroughly documented by Slack (2010). Over his lengthy career at Yale, he supervised a large number of graduate students in a program of studies often referred to as the 'Hutchinson School', many of whom became leading ecologists around North America. In addition to Riley, other Hutchinson students who later migrated to Dalhousie University included Peter Wangersky, Ian McLaren, Eric Mills, Roger Doyle andEdward Deevey. In 1971, the highest concentration of Hutchinson students (and their students) was found in the Halifax and Dartmouth area (Kohn 1971).

Hutchinson suggested that Riley investigate the copper cycle in some Connecticut lakes. While he would have preferred a biological problem, the novelty of investigating something that no one had tried before appealed to him. He carried out fieldwork in three small natural lakes (Linsley, Quonnapaug and Quassapaaug) just outside New Haven in collaboration with Hutchinson who was studying the various forms of phosphorus and nitrogen nutrients. They made observations together all seasons of the year including through the ice in winter. As well as measuring various forms of inorganic and organic copper, Riley also measured temperature, colour, transparency, alkalinity, $\mathrm{pH}$, oxygen and organic seston, and developed an improved colorimetric method for determining chlorophyll in lake water as a measure of phytoplankton biomass. In conducting his thesis research, Riley readily embraced Hutchinson's approach to science of testing hypotheses and studying variables in terms of dynamic processes such as rates of production and consumption, a quantitative synthetic approach he followed for his entire career.

While completing his doctoral thesis in early 1937, Riley received an invitation from Albert Parr, an ichthyologist and physical oceanographer who was the director of Yale's Bingham Oceanographic Laboratory, to join him on an oceanographic cruise to the mouth of the Mississippi River in the Gulf of Mexico. This two-week cruise was on Atlantis, the 142-foot ketch that was the principle research vessel of the Woods Hole Oceanographic Institution (WHOI) in 
Woods Hole, Massachusetts. Riley measured nutrients and chlorophyll and discovered that the Mississippi River carried large quantities of nutrients which produced a zone of high phytoplankton biomass near its mouth, demonstrating for the first time the important biological effect of river outflow on Gulf waters. This cruise was his first time at sea. He loved the experience and was pleased to discover that he was immune to seasickness, a trait maintained throughout his lengthy sea-going career to the envy of many colleagues. This was to be the first of many cruises on Atlantis and other oceanographic research vessels.

After this short interlude, he returned to Yale to complete and defend his thesis on the copper cycle in Connecticut lakes and its biological significance. Using multiple regression techniques, he demonstrated that precipitation, sedimentation, regeneration from sediments and release from decomposing vegetation were important factors affecting the copper content of lake water but concluded that copper had no biological significance in the lakes studied. Although conducted in a small freshwater ecosystem, this unique thesis presented a new comprehensive approach to studying aquatic ecosystems that Riley later successfully applied to studying the dynamics of biological production in the ocean.

\section{BINGHAM OCEANOGRAPHIC LABORATORY}

Upon completing his doctorate in 1937, Riley accepted a postdoctoral fellowship at Yale to undertake a seasonal plankton study in Linsley Pond, again working in collaboration with his 'guiding spirit' Evelyn Hutchinson. Over a ten-month period, he measured phytoplankton, zooplankton, chlorophyll, organic seston and phytoplankton photosynthesis and respiration. He was able to demonstrate that the use of regression equations in analyzing ecological data provided a valuable quantitative measure for evaluating complex interrelationships. He found that light and temperature were the most important factors controlling productivity in Linsley Pond.

This project came to a premature end when cottagers poisoned the pond with copper sulphate to rid it of nuisance algae. As there were no other attractive opportunities in limnology, he accepted an offer from Albert Parr of a full-time position in the Bingham Oceanographic Laboratory. Little did he know that he was initiating a stellar long- 
term career in oceanography. This was not such a major leap because he could use the same ecological principles in the ocean that he had done in Linsley Pond, although the spatial scales were vastly different.

He began this assignment by initiating some plankton studies in Long Island Sound, working out of the US Bureau of Fisheries laboratory in nearby Milford, Connecticut. This was the beginning of a long-term study of phytoplankton abundance, production and the controlling physical and chemical processes that was the prime interest of his research for many years. However, soon after starting these studies, another opportunity came along in the summer of 1938 that he decided to pursue. The Carnegie Institution of Washington had established a small marine station in the Dry Tortugas, Florida, a cluster of islands west of Key West, and was looking for some new scientific projects. Riley developed a novel proposal for a study of phytoplankton production that was accepted. The station was very isolated with no women staff but Riley welcomed the opportunity to observe the beauty of coral reefs and work on subtropical plankton. He discovered that the quantity of plankton was very low and established that nitrate was the most important limiting factor for photosynthesis.

At the end of the summer, Riley returned to New Haven and resumed his Long Island Sound studies, again working out of the Milford laboratory. His major goal was to get an understanding of the seasonal cycle of phytoplankton production in the Sound. The notorious 1938 hurricane that inflicted unprecedented damage on Long Island and New England occurred soon after his return.

His Long Island Sound studies were interrupted again in the spring of 1939 when he had the opportunity for another cruise on Atlantis of the Woods Hole Oceanographic Institution (WHOI). He joined Atlantis in Cuba and carried out plankton studies at a series of oceanographic stations on the return trip to Woods Hole with stops at Miami and Bermuda. Variables measured in the euphotic zone included temperature, oxygen, phosphate, nitrate, chlorophyll and phytoplankton production and respiration. He observed that phytoplankton production in southern waters was about half that in northern waters but due to greater transparency the maximum depth of photosynthesis was three times greater in southern waters so that production per unit area was similar. He enjoyed the cruise immensely and met several Woods Hole scientists for the first time, some who later became close colleagues, including Dean Bumpus. 
The port call in Bermuda was the first of many visits to come and, most appropriately, his first view of Woods Hole was arriving by water. He then returned to New Haven to write up his cruise results and resume his Long Island Sound studies.

This same year, WHOI began a major study of the productivity of Georges Bank under the direction of George Clarke of Harvard University. Riley was invited to study phytoplankton, plant pigments, nutrients, oxygen and phytoplankton production while George Clarke and Dean Bumpus carried out studies of zooplankton. While still living in New Haven, he took part in a series of cruises on Atlantis all seasons of the year during the period of 1939 to 1941. In his initial analysis of this extensive data set, he again used regression equations to examine the interrelationships among the variables controlling productivity. Influenced by previous work by British and Norwegian marine scientists, his approach tied together for the first time the essential variables controlling the abundance of phytoplankton over a seasonal cycle. He discovered that no single variable controlled abundance but different factors came into play at different times of the year. Solar radiation and turbulence were important during late fall, winter and early spring while nutrients, grazing and temperature were the limiting factors during the rest of the year. He also examined the theoretical relationship between vertical turbulence and the

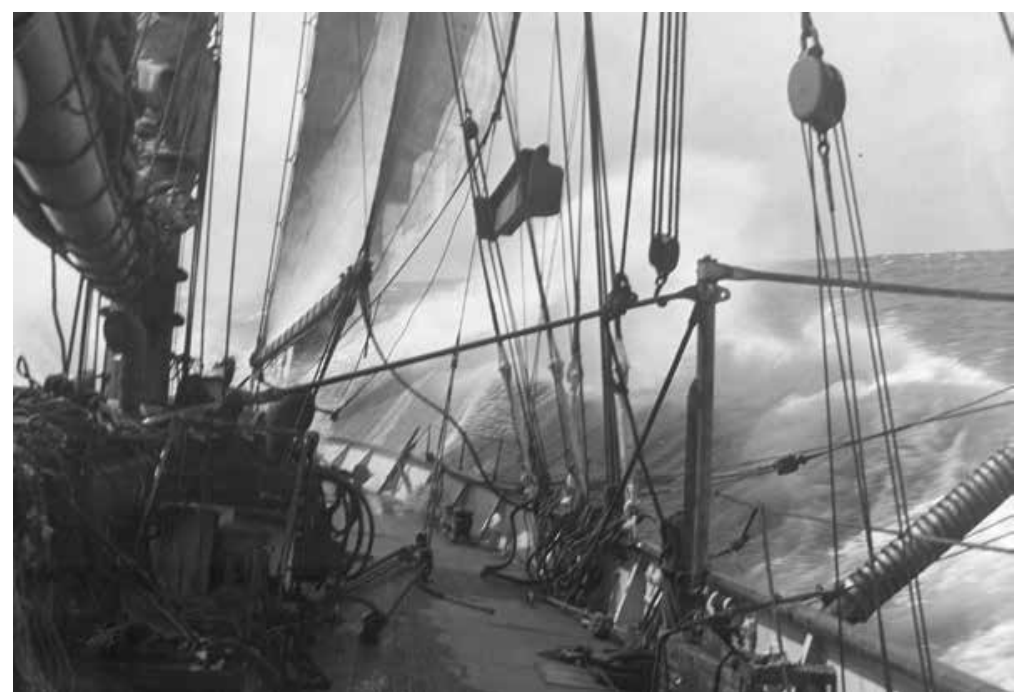

Fig 1 Photo taken by Riley in 1939 of Atlantis going to windward on Georges Bank. 


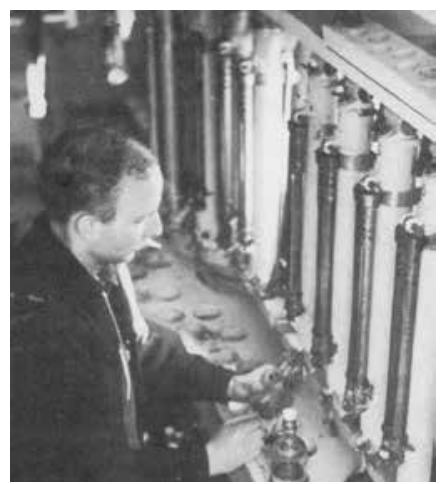

Fig 2 Riley collecting water samples for oxygen analysis from Nansen bottles on Atlantis about 1940.

spring phytoplankton bloom, as well as the physiological aspects of the spring phytoplankton bloom.

In 1939, he met a recent graduate from Yale School of Nursing named Lucy Fuller and they enjoyed numerous dates together. They were married in September of 1940.

\section{WOODS HOLE OCEANOGRAPHIC INSTITUTION}

In 1942, just after the USA entered World War II, Riley put biological oceanography aside for a few years. He turned down an offer to replace Albert Parr as director of the Bingham Oceanographic Laboratory. Instead, he accepted an offer from WHOI to work on Navy wartime contracts and moved to Woods Hole. During this period, Lucy worked in Boston and they commuted back and forth on weekends. He felt somewhat guilty not enlisting for the military but realized that he was doing important work for the Navy in support of the war effort. He was first assigned to a contract testing anti-fouling paints for amphibious aircraft. He later worked closely with a team headed by Maurice Ewing, a young geophysicist, exploring the use of the bathythermograph (BT) for predicting sound transmission in seawater. They adapted the BT for use on submarines to assist with ballasting and using acoustics to verify wreck sites along the US east coast. In time, this work took him to Miami and Key West where he gave lectures to Navy personnel on sound transmission in seawater and demonstrated the use of BTs. He was also responsible for preparing monthly charts of sound transmission conditions in the Florida Straits which involved frequent short cruises to collect 
BT data. During this period, Riley demonstrated his ability to think globally by using his earlier work on marine productivity to estimate the photosynthetic efficiency of the whole Earth which he found to be very low. In 1944, Lucy gave birth to their first daughter in Key West during a hurricane.

His first assignment upon return to WHOI was writing a small text on physical oceanography in non-technical language in collaboration with Fritz Fuglister. He was diverted in early 1945 to assist a project studying sound transmission in seawater off the mouth of the Mississippi River. This project was headed by Henry Stommel, a new WHOI employee, whom Riley met for the first time. They hit it off immediately and their lively discussions led to later collaborations in Georges Bank and North Atlantic studies. Upon return to Woods Hole, he worked on other sound transmission projects and completed the physical oceanography text. However, at this stage of his career he was eager to get back into biological oceanography and in his spare time started to work further on his earlier Georges Bank plankton data. For recreation, he purchased a Cape Cod knockabout which he enjoyed sailing in local waters.

In early 1946, soon after the conclusion of World War II, Riley was directed against his will to participate with some other WHOI scientists in Operation Crossroads, a program of two nuclear weapon tests conducted by the US military at Bikini Atoll in the Marshall Islands in the western Pacific Ocean. These were the first peacetime detonations of nuclear devices after the atomic bombing of Hiroshima and Nagasaki in August 1945. The purpose of the tests was to investigate the effect of nuclear weapons on ships. They were the first of many nuclear tests held in the Marshall Islands and the first to be publicly announced beforehand and observed by an invited audience, including a large press corps.

After steaming across the Pacific on the Bowditch, the WHOI scientific team conducted numerous baseline studies in physical, chemical and biological oceanography and fisheries around Bikini Atoll prior to the tests. This enabled the effects to be properly assessed in post-blast surveys and the flushing rate of radioactive products subsequently estimated. Riley was responsible for heading up the physical oceanographic team and work included designing and carrying out field surveys in both the lagoon and surrounding waters that required extensive seagoing operations. Riley did not enjoy this project for it took him away from his young family and he was 


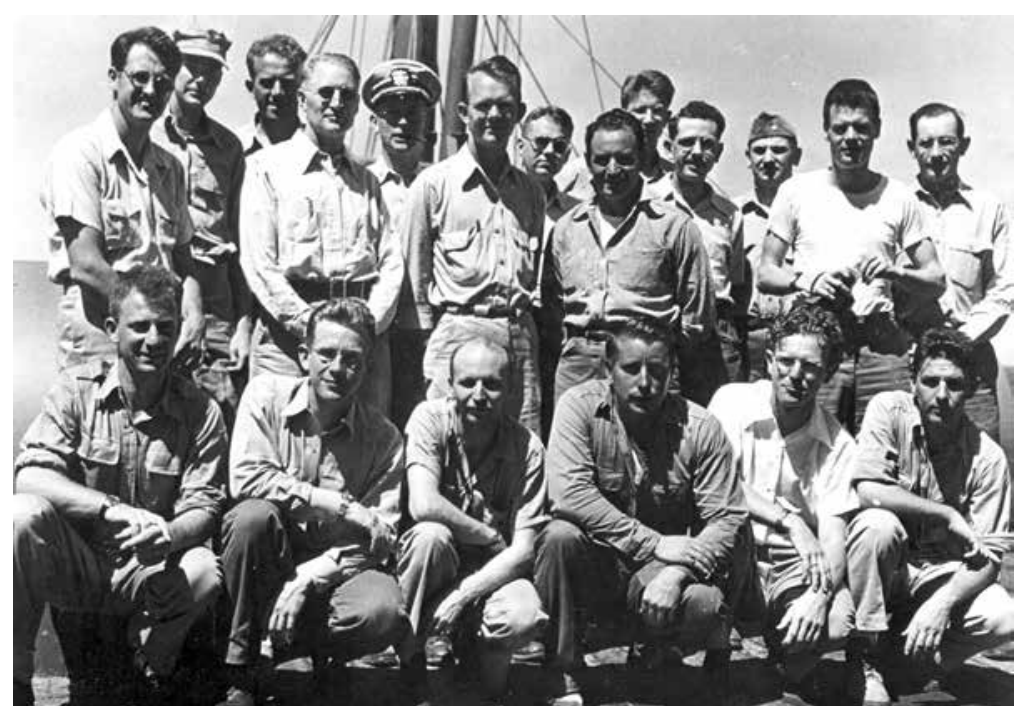

Fig 3 Scientific staff involved with Operation Crossroads on the USS Bowditch of the US Navy Hydrographic Office enroute to Bikini Atoll in 1946. Staff squatting in the first row include William Ford (second from right), Gordon Riley (fourth from right), William von Arx (fifth from right) and Walter Munk (sixth from right).

morally opposed to the development of nuclear weapons. When some of the study results were published, he refused to be an author for he did not want the world at large to know that he had been involved. Also participating in Operations Crossroads was William Ford (1913-1992) who later became the Director of the Bedford Institute of Oceanography in 1965 (Gordon 2016). Other participants who also went on to distinguished careers in oceanography included Walter Munk and William von Arx.

When Riley returned to Woods Hole, he re-joined Fritz Fuglister's physical oceanographic group assisting with the analysis of BT data collected by the Navy during the war and conducting coastal surveys, including Long Island Sound. Collaborating with Alfred Woodcock, he participated in an Atlantis cruise to study the acoustic properties of seawater east of Bermuda that included intensive BT observations to investigate physical processes in the surface layer. He later joined a project headed by Charles Fish analyzing data to explore the interrelationships between physical oceanographic properties and plankton distribution. Fish, a plankton expert, had previously worked 
for the International Passamaquoddy Power Commission in the early 1930s investigating the effects of the proposed tidal power project.

As time allowed, Riley continued to work on the Georges Bank plankton data collected before the war. In collaboration with Dean Bumpus, he examined the quantitative relationships between phytoplankton and zooplankton and concluded that the significant inverse relationship observed was due to grazing. With the availability of the zooplankton data, it was now possible to develop a relatively complete statistical treatment of the ecological relationships of the Georges Bank plankton. Accordingly, he developed equations to calculate phytoplankton abundance on the basis of controlling factors such as temperature, depth of water, nutrients and zooplankton and obtained good agreement with observed values. He also evaluated the seasonal cycle of phytoplankton from a more theoretical framework using differential equations. He postulated that the rate of change of phytoplankton abundance was equal to the difference between the photosynthesis rate and that of respiration and zooplankton grazing. The resultant curve over the seasonal cycle showed good agreement with observed values. Using similar methods, he also constructed a theoretical seasonal curve of zooplankton abundance that was also in general agreement with observations.

In 1947, Riley participated in an Atlantis cruise to Sargasso Sea and conducted quantitative studies of summer plankton. He observed that phytoplankton biomass and production rates were much lower than observed in New England coastal waters and offshore banks.

Working in collaboration with Dean Bumpus and Henry Stommel, Riley carried out further studies of the quantitative ecology of plankton in the western North Atlantic based on the available data from the region. Theoretical equations were developed to explain the distribution of variables on the assumptions that any marine population is quantitatively controlled by the processes that increase or decrease the organic content of the population and that the rates of the processes are determined by a complex of environmental factors that acts by affecting the physiology of the organisms and their physical dispersal. The most important environmental factors were found to be radiation, transparency, temperature, vertical eddy diffusivity and phosphate. He also developed a theoretical food chain. 


\section{BINGHAM OCEANOGRAPHIC LABORATORY}

In 1947, Lucy gave birth to their second daughter. While Riley and his young family were very content in Woods Hole, with the end of wartime contracts there was considerable uncertainty about the future nature of oceanographic research at WHOI. As a result, Riley started looking for other opportunities. He was offered a job by Johns Hopkins University to develop a new oceanographic laboratory on Chesapeake Bay but declined. However, in 1948, he accepted an offer to return to the Bingham Oceanographic Laboratory at Yale and, somewhat reluctantly, the family moved back to New Haven. Not much had changed at the Bingham laboratory during his sixyear absence. It remained a small lab of marine biologists, not a true oceanographic laboratory with seagoing programs.

Once settled in back at Yale, Riley initially turned his attention to Block Island Sound off Rhode Island and carried out studies of its hydrography and phytoplankton. He conducted an analysis of the physical oceanographic processes that produced the observed distribution of temperature and salinity and documented the seasonal cycle of phytoplankton abundance. Under his coordination, colleagues at Yale and the University of Rhode Island carried out associated studies of zooplankton, fish eggs and larvae and herring.

Riley then began investigating biological processes in the deep-sea. Vertical profiles of oxygen, phosphate and nitrate provided convincing evidence that oxygen was consumed and nutrients regenerated in deep water below the euphotic zone. He used existing data to examine the deep circulation of the Atlantic Ocean and developed estimates of food requirements and metabolic rates of deep-sea organisms. He calculated from oxygen consumption and phosphate regeneration that approximately one-tenth of the surface production by phytoplankton was utilized in the entire water column. These studies were highly original and the results have largely stood the test-of-time, including the findings of the Geochemical Oceans Sections Program (GEOSECS) carried out over twenty years later.

At this time, Riley also worked with phytoplankton samples and BT data that were collected in the Sargasso Sea on a regular basis as part of the US Weather Ship program. This data set allowed him to investigate phytoplankton variability over time at one location in subtropical offshore surface waters. He observed a spring bloom 
similar to that observed in temperate coastal but that phytoplankton production was about one third lower.

In 1950, Riley and family spent several months at the Scripps Institution of Oceanography in La Jolla, California, where he served as a visiting professor and gave a series of lectures on plankton. He also examined data collected during a large-scale oceanographic program off the California coast and offered recommendations for improving its design. Riley enjoyed the visit and interaction with Scripps' scientists, especially Walter Munk. They collaborated in a unique theoretical modelling study of the absorption of nutrients by aquatic plants that considered various factors including size, specific gravity, nutrient concentrations and physical properties.

Riley did not have a formal academic appointment at the Bingham Oceanographic Laboratory but did start to take on graduate students through the Department of Zoology. Building upon his earlier work in Long Island and Block Island Sounds, in 1952 he established a major field program with his graduate students to carry out a longterm study of the major components of the productive Long Island Sound coastal ecosystem. Frequent cruises were carried out during all seasons over four years. Riley covered the physical and chemical oceanography of the Sound while Shirley Conover investigated the phytoplankton, Georgiana Deevey and Robert Conover studied the zooplankton and Howard Sanders examined the benthos. Riley was able to calculate the transport of water into and out of the Sound at different times of the year. Further information was collected on the seasonal cycle of phytoplankton and Riley calculated that production of Long Island Sound was twice that observed in the English Channel. This ambitious undertaking was one of the first comprehensive studies of a large coastal ecosystem conducted anywhere. With the exception of Howard Sanders, under the influence of Riley these graduate students later moved to Nova Scotia and became prominent in the local marine science community.

Another graduate student participating in the Long Island Sound program was Eugene Harris who arrived from Dalhousie University after completing a master's degree under Ronald Hayes. He initiated a study of the nitrogen cycle in the Sound but unfortunately came down with cancer and passed away before completing his degree. Following his death, Riley wrote up his research results and published them under Harris's name with a footnote explaining that he had compiled the paper posthumously as a memorial. During this 
period, Riley also served on the supervisory committees of several of Hutchinson's graduate students, including Peter Wangersky, Eric Mills and Ian McLaren, all of whom later joined the faculty of Dalhousie University.

Throughout the late 1950s and early 1960s, Riley and colleagues carried out further oceanographic studies in Long Island Sound that considered water transparency, surface currents using drift bottles, nutrients, particulate matter, microbiology and benthic fauna. With almost thirty years of sustained study under his leadership, Long Island Sound had become one of the best understood coastal ecosystems in North America.

In early 1952, Riley traveled to Ottawa to give an invited paper on the application of theoretical population principles to ecology at a meeting of the Canadian Fisheries Society. This was his first trip to Canada and provided him with the opportunity to meet leading Canadian aquatic scientists for the first time, including Ronald Hayes from Dalhousie University that would loom important later in his career. Soon after he returned to New Haven, Lucy gave birth to their third daughter.

As expected for a scientist with a growing reputation, during the 1950s Riley became involved in numerous external scientific activities. For example, he was elected to the Board of Trustees of the Bermuda Biological Station and later served as president. He was a member of an advisory committee for the Narragansett Marine Laboratory at the University of Rhode Island (which later evolved into the Graduate School of Oceanography) as well as advisory panels to review grant applications for the Office of Naval Research and National Science Foundation. He participated in a series of three annual conferences at Princeton University where free and informal discussion among a group of scientists was tested as a more effective way of disseminating knowledge than sessions of formal papers. These conferences enabled him to interact with other leading North American, British and European marine scientists including Einer Steeman-Nielsen, Ramon Margalef, Trygve Braarud and John Strickland. He was also a member of the US National Academy of Sciences Committee on Oceanography (NASCO) that was charged with reviewing the state of oceanography in the US, a field of science that had been growing rapidly after the war, and with making recommendations for further development. This involvement over five years, with other leading 
US oceanographers, resulted in an influential book that laid out a framework for orderly growth in US oceanography.

For many years, Riley sought a formal academic appointment at Yale in the Zoology Department in recognition of his service to the university and to make it easier for supervising his graduate students. He was most pleased when he was finally appointed as Professor of Oceanography in 1959. However, his long-term goal was to create a separate department of oceanography at Yale. His previous experience with the NASCO review had helped crystalize his thinking of how a university oceanography department should be organized and operated and there was an increasing demand for well-trained oceanographers. Riley started to work in this direction by bringing new scientists from other marine disciplines into the Bingham laboratory. One of these was Peter Wangersky, a chemical oceanographer who had also been one of Hutchinson's graduate students.

Riley's research interests underwent another major shift in the late 1950 s. He became interested in dynamics of particulate organic matter in seawater. He observed in Long Island Sound that organic detritus was more abundant than phytoplankton in surface water and showed little correspondence to the seasonal production cycle of phytoplankton. He suspected that the traditional viewpoint that particulate organic matter degraded into smaller particles and ultimately dissolved with little ecological role may not be completely correct and that there may be ecologically significant processes operating in the opposite direction. In collaboration with Satoshi Nishizawa, a post-doctoral fellow from Japan, Riley expanded his research program in Long Island Sound to study organic aggregates. These are amorphous particles containing both organic and inorganic materials with inclusions of bacteria and phytoplankton. He found that organic aggregates appeared to be formed mainly by adsorption of dissolved organic matter on bubbles, a process readily duplicated under laboratory conditions, and speculated that they could be an important alternative food source for zooplankton. This program expanded to include observations of organic aggregates in the tropical and subtropical North Atlantic in collaboration with Peter Wangersky, using Trident, the research vessel of the Graduate School of Oceanography in Rhode Island. He demonstrated that organic aggregates are of ecological significance in both oceanic and coastal environments.

During this period, Riley renewed his ties with the Bermuda Biological Station and for two summers helped teach a graduate course 


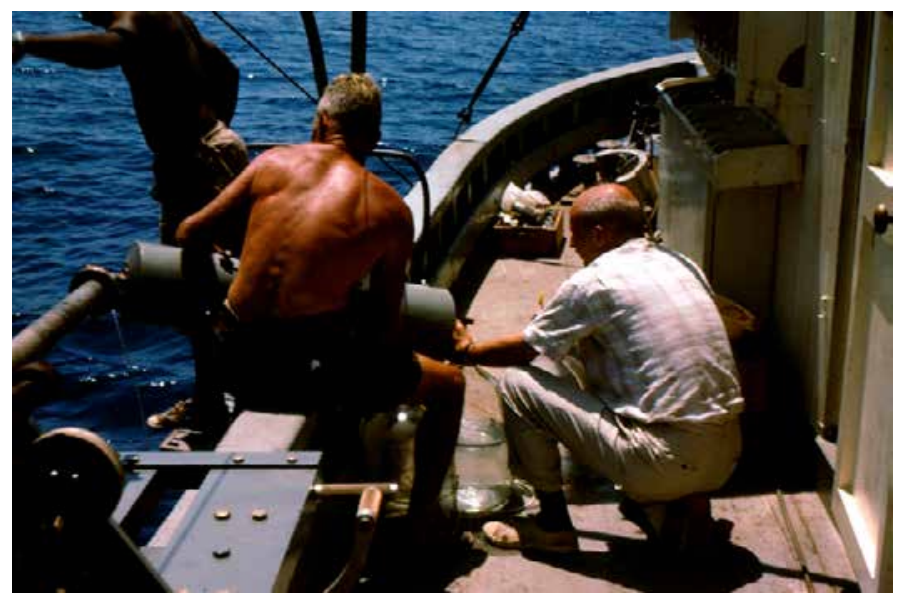

Fig 4 Riley drawing water samples on the Panulirus of the Bermuda Biological Station in 1964.

on animal-sediment interrelationships. In 1961-1962, he served as president of the American Society of Limnology and Oceanography

Meanwhile, his attempts to develop a department of oceanography at Yale were unsuccessful. Riley was getting frustrated and restless. He saw no future for the Bingham Oceanographic Laboratory so, in 1964 at the age of 54, he decided the time had come to look elsewhere. He was at the peak of his career and, as word got around that he was looking for a new appointment, he started to receive numerous offers. These included the nearby Graduate School of Oceanography at the University of Rhode Island and the University of Alaska.

\section{DALHOUSIE UNIVERSITY}

In the late summer of 1964, Peter Wangersky visited Dalhousie University to be interviewed for a job with the Institute of Oceanography. This institute had been created in 1959 as part of the growing Canadian oceanographic community, ten years after the creation of the Institute of Oceanography at the University of British Columbia (Mills 1994). He was quite impressed with the potential of the young institute and learned that it was seeking a new director to take over from Ronald Hayes who had recently moved to Ottawa to become the Chairman of the Fisheries Research Board of Canada. Upon return to Bingham, he recommended to Riley that he apply. 
Riley wisely heeded this advice and within a few weeks came to Dalhousie for an interview. Riley and President Henry Hicks hit it off immediately and he too was impressed with what he saw. Although the Institute was small, there were many positive features and great potential for growth. Institute staff had sole responsibility for the admission of graduate students, the formulation of curriculum and recommendations for degrees. Ship time on federal research vessels operated by the Bedford Institute of Oceanography (BIO) across the harbour was available without charge and there was a substantial block grant from the National Research Council for general operating expenses. The only negative aspect of concern to Riley was that professional appointments of Institute staff were in the associated basic science departments, which therefore controlled appointments, promotions and tenure. Soon after Riley returned home, he was offered the position and immediately accepted. Leaving the United States was a difficult decision to make but he felt the Dalhousie position offered great potential to develop the department of oceanography he had envisioned. And, most fortunately, Lucy and the family were agreeable to the move. His career was now about to take another major change in direction.

The Riley family arrived in Halifax in July 1965 and moved into a house on Vernon Street, just a short walk from his new office in the basement in the Forrest Building on the Carleton Campus. A few months earlier, William Ford, his good friend from WHOI days, also arrived in Halifax to become the new director of BIO (Gordon 2016). Hence, a friendly and collaborative relationship across the harbour was assured.

The principal mandate of the Institute was to produce oceanographers for the federal research laboratories that were rapidly expanding across the country at the time. When he arrived, Institute full-time associates were Michael Keen (geophysics), Daniel Stanley (sedimentary geology), Donald Swift (sedimentary geology), Carl Boyd (zooplankton ecology) and E.H. Anthony (microbiology). In addition, Peter Wangersky (chemical oceanography) arrived with Riley from Yale to join the Institute. There were no physical oceanographers on staff at the time but these courses were taught by Earlston Doe and Ronald Trites, honorary lecturers from BIO. A. Levin (engineering physics), Bosko Loncarevic (geophysics) and Cedric Mann (physical oceanography) were part-time associates. There were 21 graduate students, mostly in biology and geology. Staff and students 
were physically housed in their home departments spread across the campus. The Institute supported field stations at Baddeck on the Bras d'Or Lakes and Purcell's Cove at the mouth of the Northwest Arm.

As director of the Institute of Oceanography, Riley's duties were primarily administrative. He soon began to recruit new faculty members to expand and broaden the expertise of the Institute to cover all the major oceanographic disciplines. He sought out highly qualified young faculty members and promoted an open and free attitude to research. These early additions included Walton Watt (phytoplankton ecology), Eric Mills (benthic ecology), Roy Hyndman (geophysics), Roy Overstreet (physical oceanography), Christopher Garrett (physical oceanography), Robert Cook (chemical oceanography) and Robert Fournier (biological oceanography). Riley also played a roll in recruiting Robert Conover and William Sutcliffe for the Marine Ecology Laboratory at BIO.

Soon after he arrived, with the full backing of President Henry Hicks, Riley started to work on plans to convert the Institute into a Department of Oceanography, a process that took several years to bring to fruition. In so doing, he met with some opposition from other science department heads (Waite 1998) but with time this was overcome. He was also appointed to chair the building committee charged with planning the new Life Sciences Centre for the Oceanography, Biology and Psychology departments. This task, which included planning the Aquatron running seawater facility, was a major time commitment. In addition, he was involved in numerous external activities including various National Research Council grant committees and the Canadian Committee on Oceanography, as well as numerous US scientific committees.

Despite this heavy administrative load, Riley continued to participate as much as possible in scientific activities. He taught a course in biological oceanography and supervised graduate students. With the assistance of associates, he continued his research on nonliving organic matter in seawater, including laboratory experiments examining the role of bacteria in the dynamics of organic aggregates. He also brought his work in Long Island Sound to completion, developed additional plankton models and wrote several major review articles. Whenever he could, he enjoyed going to sea with graduate students on BIO research vessels.

Riley and family settled well into life in Halifax. Lucy resumed her nursing career and later became actively involved in the 
Unitarian Church, the New Democratic Party and senior's issues. They both were particularly impressed with the amount of relatively wild country so close to the city and, in 1966, bought a large acreage of woodland with a cottage on Cox Lake in Yankeetown, just outside Halifax. This was Riley's first introduction to boreal forests and he immediately loved them. Weekends in the country became very important to them both. He enjoyed exploring his property and adjacent crown lands and building a network of trails while Lucy enjoyed looking after her garden. He became very proficient in using a chain saw and enjoyed thinning trees, cutting firewood and crafting rustic furniture. They welcomed visits from oceanography graduate students who came out for picnics, paddling, hiking and cross-country skiing. Whether paddling a canoe, tramping in the woods or working with wood, Riley found a sense of peace that he had not experienced for a long time. The woods and waters became his 'church' where he completely relaxed. He was beginning to put down roots for the first time since leaving his boyhood home in the Ozarks.

In 1970, he was offered the Captain Cook Chair of Oceanography at the University of Hawaii but by this time he had no interest in leaving his new home in Nova Scotia and trading its variable weather for constant summer.

Riley's administrative skills bore fruit with two major events at Dalhousie University in 1971. The first was completing the conversion of the Institute of Oceanography into the Department of Oceanography. Creating a department of oceanography, including all major disciplines, had been his goal for many years. He had attempted to do this at Yale but did not get the support of the university administration. He took great pride in accomplishing this feat at Dalhousie. The second event was the completion of the Life Sciences Centre which brought the new Department of Oceanography together, under the same roof for the first time, along with the Departments of Biology and Psychology. Riley was pleased that all faculty and graduate students would now have offices and laboratories larger than what he had had in the basement of the Forrest Building.

Riley's last oceanographic cruise was in March 1972, thirty-five years after his first on Atlantis. He joined a team of BIO and Dalhousie colleagues in Bermuda for a return trip on Dawson to BIO. Soon after departing St. Georges, the ship encountered a severe storm and had to heave to in heavy seas for several days. All scientific operations were suspended. Riley was one of the few members of the scientific 


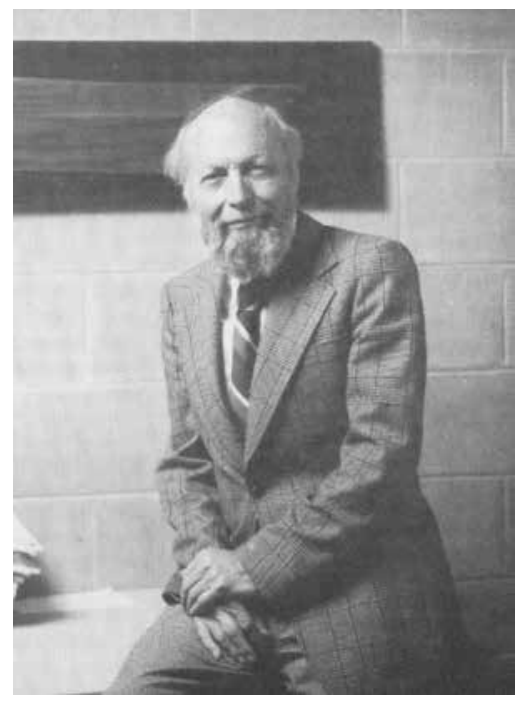

Fig 5 Riley in his new office in the Department of Oceanography in 1971. In the background is a half model of Atlantis.

party to show up for meals on a regular basis. Unfortunately, the violent motion of the ship inflicted some injuries and Riley realized that he no longer had the endurance to work at sea.

Most fittingly, in 1973 Riley was elected as a Fellow of the Royal Society of Canada. He took particular delight in this accolade to "a boy from the Ozarks".

By 1974, Riley felt burned-out as an administrator and resigned as department chairman. However, he still taught his biological oceanography course and supervised graduate students. He enjoyed having more time to read and catch up on the scientific literature. The same year, he and Lucy built a new road and larger cottage on their land on Cox Lake and sold the original cottage to Ken Mann, Chairman of the Dalhousie Biology Department.

In 1976, Riley was, most appropriately, awarded the prestigious Rosenstiel Award in Ocean Sciences by the University of Miami in recognition of his outstanding lifetime achievements in oceanography. The same year he decided that the time had come to retire and was appointed Professor Emeritus.

In 1982, his Dalhousie colleagues produced a volume of his most influential scientific publications which were reprinted in their entirety (Wroblewski 1982). Many of these papers were classics and are as relevant today as when they were first published. This wonderful tribute included a foreword by Henry Hicks and essays by Evelyn 
Hutchinson, Eric Mills, Robert Fournier, Peter Wangersky and Edward Deevey. His other scientific publications are also listed in this commemorative volume.

Riley enjoyed nine years of retirement. He and Lucy sold their house and moved into a nearby condominium on Coburg Road. He put considerable effort into writing his personal memoirs which he privately shared with family and close associates. They spent as much time as possible at Cox Lake where Riley continued to enjoy his favourite activities, both in the woods and on the water.

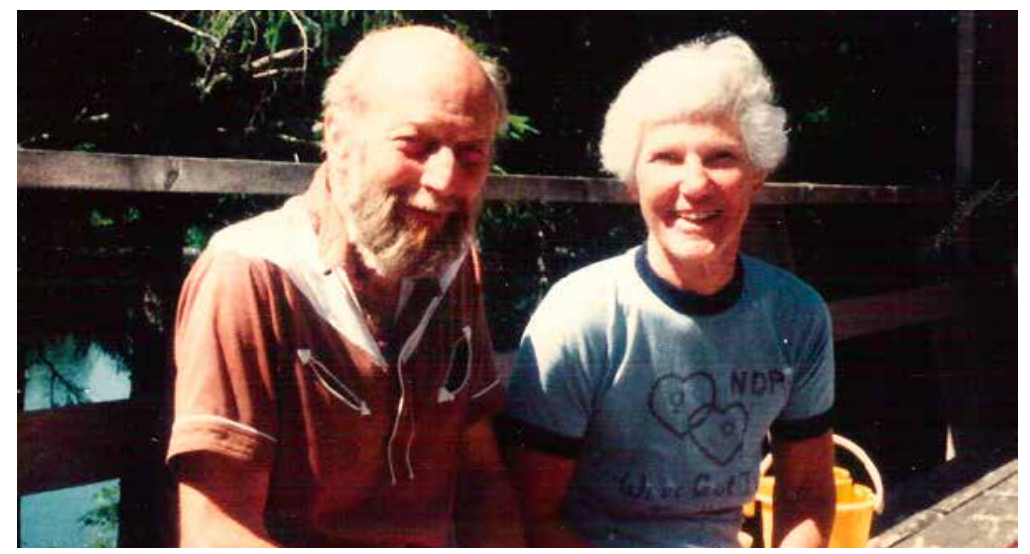

Fig 6 Gordon and Lucy Riley at their camp on Cox Lake in 1980.

He developed an interest in wood carving and created numerous carvings of local wildlife. He also began to write poetry and one of his many reflective poems is presented below.

After a long battle with cancer, Riley died in 1985. His ashes were spread in his beloved woods at Cox Lake. Fitting tributes were written by Evelyn Hutchinson (Hutchinson 1986) and Lloyd Dickie (Dickie 1987). In his memory, the Department of Oceanography created the Riley Lecture, given annually by a prominent oceanographer selected by its graduate students. The private road leading to the Cox Lake cottage was later named Riley Road by the County of Halifax. Lucy continued to enjoy using the cottage for another twenty years and when she passed away her ashes too were spread in the woods with Gordon's. 


\section{SYNOPSIS}

Gordon Riley was a pioneer in oceanography. His multidisciplinary approach, quantitative skills, imagination and intuition advanced our knowledge and understanding of the ocean enormously. He believed that science is fundamentally an artistic endeavour and enjoyed the aesthetic pleasure of trying to fit the fragmentary facts into a logical picture. In the early stages of his career, oceanography was a relatively small field of study and Riley personally knew and interacted with many of the major players. These included Maurice Ewing, Henry Stommel, Dean Bumpus, Alfred Woodcock, Columbus Iselin, William von Arx, Fritz Fuglister, Alfred Redfield, Bostwick Ketchem, George Clarke, Raymond Mongomery, Roger Revelle, Harald Sverdrup and Walter Munk. His personality led to unusually effective collaborations with other notable scientists in the various oceanographic disciplines.

Riley was always a lover of the natural world. His career was firmly rooted in observation. He worked before the advent of electronic sensors, satellites and computers in the age when field and laboratory work was done mostly by hand. Temperature was measured at discrete depths using reversing thermometers, water was collected using sampling bottles strung on hydrographic wire and zooplankton were collected by nets. Analyses of oxygen, chlorophyll and nutrients in seawater were carried out using laborious wet chemical techniques on shipboard or later in a laboratory ashore. There were no computers so data processing was limited to pencil and paper, slide rule and mechanical calculators. With these limitations in data collection and processing, Riley was forced to think carefully about the basic questions he was asking and make sure he was gathering the most essential data to answer them. He was a genius in using a limited amount of carefully collected information to provide profound insight into important oceanographic processes. A hallmark of his work was demonstrating the complexity of these processes with an apparent simplicity and clarity that provided direction for the development of biological oceanography for over thirty years (Mills 2012).

Riley was particularly well known for his work on developing mathematical models of phytoplankton dynamics. His great achievement lay not so much in the simulation of plankton dynamics per se but rather in promoting the concept of using modelling as a tool for understanding the dynamics of marine ecosystems. He demonstrated that simple models with formulations chosen carefully on the basis 
of observation and experiment could be used to provide valuable insight into ecosystem dynamics. His models of planktonic dynamics on Georges Bank are considered milestones in the history of marine ecosystem modelling (Anderson and Gentleman 2012). In a recent review of the history of ecological sciences between 1920 and 1970, Riley's contributions were put in the same category as those of Rachel Carson, Jacques Cousteau and Eugenie Clark (Egerton 2017).

Riley was a very modest and quiet person who withdrew in a crowd and never sought the spotlight he deserved. He was an unsung hero who possessed a remarkable independence of mind as well as a dry wit and talent for pungent statement. He maintained the highest of professional standards but could be a bit irreverent in his contempt of colleagues who did not. He had a strong dislike of academic formality and never hid behind a screen of rank and authority. He treated his students and technical assistants as equals, considered them as 'family' and insisted they call him by his first name. He was always approachable, took a personal interest in their lives and enjoyed social interactions outside of the laboratory. Graduate students were amazed how he and Lucy enjoyed coming to their parties. Riley refused to put his name on the research papers written by his students because he wanted them to stand scientifically on their own. He never discouraged them from thinking differently and often said it would not be any fun if all his students agreed with him. Throughout his career, Riley encouraged the participation of women in science and one third of his co-authors were women. He commanded the highest respect from all that knew him.

Dalhousie University was extremely fortunate to have landed Gordon Riley. Had the Yale University administration supported his desire to create an oceanography department, he probably would never have left for Canada. He was looking for a change in his career and the Institute of Oceanography was looking for a new director. It was a perfect fit, with perfect timing. He and Lucy quickly adjusted to their new lives in Halifax, became an integral part of the local community and never looked back.

Riley's most outstanding administrative success was the creation of the Department of Oceanography at Dalhousie University. The previous Institute of Oceanography had been a loosely associated group of scientists primarily pursuing their own particular disciplinary interests in the ocean. From his extensive previous experience in the US oceanography community, he knew exactly how the new 
department should be organized and administered. Under his guidance and tutelage, staff and students alike began to realize that oceanography was more than the sum of its parts and that addressing the interaction of physical, chemical, biological and geological processes was critical to understanding oceanographic processes. Working from the foundation he built, the department soon developed into a major international centre for oceanographic research and education, a feather in the hat for Dalhousie University.

The essence of Gordon Riley and his work is well captured in the following quotes:

"The meek may ultimately inherit the Earth; Gordon has shown that the modest may inherit the Sea." G. Evelyn Hutchinson

"Riley's first paper on Long Island Sound is one of the most significant in all plankton ecology because it illuminates knowledge that had accumulated for forty years in the powerful light of statistical analysis and experiment. His results have a paradigmatic quality that is virtually absent in even the most important of earlier works. He applied quantitative techniques with considerable success to the study of plankton dynamics, and equally important, the logical grounds for evaluating causative factors in plankton dynamics were persuasively presented.” Eric L. Mills

"Reading Gordon's papers, I am always reassured that one good man with good ideas capable of using his native inborn insight, intuition and awareness can make important, lasting and elegant contributions." Robert O. Fournier

"Riley was remarkably self-critical in his outlook and writing, displaying a discerning and shrewd rationality of thought in his approach to science”. Thomas R. Anderson and Wendy C. Gentleman

Acknowledgements First and foremost I thank Gordon for bringing me with him to Halifax in 1965 as a graduate student, a move that had a profound impact on my life and scientific career. He was a wonderful mentor, colleague and close friend who set a wonderful example to follow. I am indebted to him for giving me a copy of his personal memoirs that were the source of much of the information in this article. I thank his daughters Louise Gemeinhardt, Grace Riley 
and Milly Riley for ensuring the accuracy of the more personal aspects of Gordon's life. Eric Mills, Robert Fournier, Gareth Harding and Jonathan Sharp checked the accuracy of the scientific content and, along with Joleen Gordon and three anonymous reviewers, kindly offered numerous suggestions for improvements. And finally, I thank Lucy Riley and her daughters for selling the Cox Lake property to my family so that we could continue to maintain the Riley legacy with fond memories for many more years.

\section{REFERENCES}

Anderson, T.R., \& Gentleman, W.C. (2012). The legacy of Gordon Arthur Riley (1911-1985) and the development of mathematical models in biological oceanography. Journal of Marine Research 70: 1-30.

Dickie, L.M. (1987). Gordon Arthur Riley 1911-1985. Transactions of the Royal Society of Canada, Series V, Volume II: 256-258.

Edmondson, Y.H.(ed.). (1971). Some components of the Hutchinson legend. G. Evelyn Hutchinson Celebratory Issue. Limnology and Oceanography 16: 157-161.

Egerton, F.N. (2017). History of ecological sciences, Part 58B: Marine ecology, mid-1920s to about 1990: Carson, Riley, Cousteau and Clark. Bulletin of the Ecological Society of America 98: 113-149.

Gordon, D.C. (2016). The life and career of William Livingstone Ford (1913-1992). Proceedings of the Nova Scotian Institute of Science 48: 173-188.

Hutchinson, G.E. (1986). In memoriam: Gordon A. Riley (1911-1985). Limnology and Oceanography 31: 233.

Kohn, A.J. (1971). Phylogeny and biogeography of Hutchinsonia: G.E. Hutchinson's influence through his doctoral students. G. Evelyn Hutchinson Celebratory Issue. Limnology and Oceanography 16: 173-176.

Mills, E.L. (1994). Bringing oceanography into the Canadian university classroom. Scientia Canadensis 18: 3-21.

Mills, E.L. (2012). Biological oceanography; an early history, 1870-1960. University of Toronto Press, Toronto, ON. 378 p.

Slack, N.G. (2010). G. Evelyn Hutchinson and the invention of modern ecology. Yale University Press, New Haven, CT. 457 p.

Waite, P.B. (1998). The lives of Dalhousie University; Volume Two, 19251980. McGill-Queens University Press, Montreal, QC. 478 p.

Wroblewski,J.S. (ed.). (1982). Selected works of Gordon Riley. Dalhousie University, Halifax, NS. 489 p. 


\section{SELECTED PUBLICATIONS}

Over his career, Gordon Riley published on the order of 70 research papers (Wroblewski 1982). Those listed below are representative of his important scientific contributions over his lengthy career as an oceanographer.

Riley, G.A. (1939). Correlations in aquatic ecology. Journal of Marine Research 2: 56-73.

Riley, G.A. (1941). Plankton studies. IV. Georges Bank. Bulletin of the Bingham Oceanographic Collection 7: 1-73.

Riley, G.A. (1946). Factors controlling phytoplankton populations on Georges Bank. Journal of Marine Research 6: 54:73.

Riley, G.A., Stommel, H., \& Bumpus, D.F. (1949). Quantitative ecology of the plankton of the western North Atlantic. Bulletin of the Bingham Oceanographic Collection 12: 1-169.

Riley, G.A. (1951). Oxygen, phosphate and nitrate in the Atlantic Ocean. Bulletin of the Bingham Oceanographic Collection 13: 1-126.

Riley, G.A. (1952). Hydrography of the Long Island and Block Island Sounds. Bulletin of the Bingham Oceanographic Collection 13: 5-39.

Riley, G.A. (1959). Oceanography of Long Island Sound. Bulletin of the Bingham Oceanographic Collection 17: 9-30.

Riley, G.A. (1963). Organic aggregates in seawater and the dynamics of their formation and utilization. Limnology and Oceanography 8: 372-381.

Riley, G.A. (1967). Mathematical model of nutrient conditions in coastal waters. Bulletin of the Bingham Oceanographic Collection 19: 72-80.

Riley, G.A. (1970). Particulate organic matter in sea water. Advances in Marine Biology 8: 1-118.

\section{DOCTORAL GRADUATE STUDENTS}

(and subsequent professional affiliations)

\section{Yale University}

Howard Sanders (Woods Hole Oceanographic Institution)

Robert Conover (Woods Hole Oceanographic Institution,

Bedford Institute of Oceanography)

Rudy Haffner (Wesleyan University)

Eugene Harris (Died while a student)

Gerald Posner (Unknown)

David McGill (Woods Hole Oceanographic Institution)

Elizabeth Wood (Unknown)

Andrew Carey (Oregon State University)

William Pearcy (Oregon State University)

Theodore Napora (University of Rhode Island) 


\section{Dalhousie University}

Donald Gordon (University of Hawaii, Bedford Institute of Oceanography) Janet Eaton (Mount Saint Vincent University)

Jonathan Sharp (University of Delaware)

Gareth Harding (Bedford Institute of Oceanography)

Colin Duerden (Environment Canada)

Shirley Conover (Environmental consulting industry)

Patricia Johansen (Died soon after completing her degree)

John Marra (Lamont-Doherty Earth Observatory, Brooklyn College) 


\section{A REPRESENTATIVE POEM}

\section{Musings of an Old Oceanographer}

Tropical night, a lazy swell

And a palely luminescent wake,

Or sailing before a spanking breeze

With only a softly whispering sound

Of water swishing past the hull,

Or then again the wild shriek

Of a gale in shrouds and sheets

And the creaking of the tortured hull

And flying spume and crashing waves

With every laboured pitch.

These are memories of the sea

And thoughts and feelings about it,

Varied as the moods of the sea

And ordered by its restless change.

There are secrets to be sought

By wearisome work; we're often cold

And wet, and that's fair weather work,

'Til a roaring storm gives us time

For a little uneasy rest.

This is our life aboard the ships;

Why do we do it? I suppose

They'd say it's the lure of the sea,

And there's always beauty and lure,

But I wonder if those who love the sea

Really know the sea; it dwarfs

That kind of human emotion.

I think for us there's a different need,

Not a drive to cross its vast expanse

Nor a challenge to brave its restless might.

Well, perhaps a little of those,

But there's always a greater passion.

Returning to the life ashore

And driven by curiosity

To puzzle over the things we've found -

And call it science or call it art -

Trying to weave all the scattered facts

Into a logical tapestry

That helps us better understand

The mystery of the sea. 
